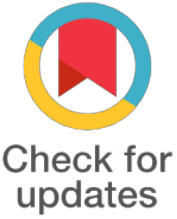

*For correspondence:

dotrungkienbio@gmail.com

Competing interests: The authors declare that no competing interests exist.

Received: 2017-06-01

Accepted: 2017-07-04

Published: 2017-09-05

Copyright The Author(s) 2017. This article is published with open access by BioMedPress (BMP).

This article is distributed under the terms of the Creative Commons Attribution License (CC-BY 4.0) which permits any use, distribution, and reproduction in any medium, provided the original author(s) and the source are credited.

\section{Differentiation Potential and Characteristics of Mesenchymal Stem Cells Isolated from Human Umbilical Cord membrane to Hepatocyte-like Cells}

\author{
Trung Kien Do, Van Hanh Nguyen, Huu Duc Nguyen, Chu Hoang Ha \\ Biotechnology Institute, Vietnam Academy of Science and Technology, Hanoi, VietNam
}

\section{Abstract}

Recent studies indicated that Mesenchymal stem cell has become a potential objective for therapy. In this study, umbilical cord cells were isolated and analyzed the expression of mesenchymal stem cells specific markers then they were differentiated into hepatocyte-like cells by DMSO and Gene transfection. Umbilical cord mesenchymal stem cell (MSC) was isolated by explant culture in media DMEM/F12, complementing with growth factors EGF, FGF and IST. After that, they were exposured to DMSO with three concentrations: $0.01 \%, 0.1 \%, 1 \%$ and another group was transfection with $\mathrm{HNF}_{4} \alpha$ by Lipofectamin LX plus. The cells were analyzed at $1,2,3$, and 4 weeks after treatment. The cells isolation was shown the positive with markers $\mathrm{CD}_{73}, \mathrm{CD}_{34}$, CD86, CD90, CD105, eras, Oct 1, GATA, and negative with markers HNF4 $\alpha$, Alb and G6P. In group $0,1 \%$ DMSO treatment, after 3 weeks the cells were positive with markers $\mathrm{HNF}_{4} \alpha$ but it was also negative with markers Alb and G6P. In the transfection group, the cell expresses $\mathrm{HNF}_{4} \alpha$ at three weeks after treatment. Although our results exposure that the umbilical cord mesenchymal stem cells expressed hepatic specific marker after DMSO induced and DNA treatment. So it will be necessary to optimize research conditional and investigate the hepatic functions of these cells in a longer in vitro culture.

\section{Keywords}

Differentiation, Hepatocyte-like cell, In vitro culture, DMSO, Gene transfection, Umbilical cord stem cells

\section{Funding}

This study was funded from: "Study on the differentiation of hepatocytes from human and mouse stem cells ", code: VAST.LL.03 / 16-17.

\section{References}

